\title{
BHAMBATHA AND THE ZULU REBELLION \\ 1906
}

\author{
Paul S. Thompson
}

\section{Centenary Celebrations}

In 1906 there occurred a rebellion among a part of the indigenous people against the settler government of the British colony of Natal, ostensibly against the collection of a poll (capitation) tax on adult males. It is very often called the Zulu Rebellion, but it has many names, and it is commonly called "Bhambatha's rebellion" or "the Bhambatha rebellion", after the most famous of its leaders. ${ }^{76}$ The centenary of the rebellion was marked by public celebrations of a political character which however shed very little light on the actual historic events.

These celebrations were sponsored by the provincial government, usually in collaboration with ad hoc local bodies. They commenced when the provincial premier announced that Bhambatha would be posthumously reinstalled as a chief. There followed the laying of wreaths at memorials at Mpanza, near Greytown on 8 April 2006, followed by a cleansing ceremony and the dedication of a memorial wall to the "Richmond Twelve" on 22 April. They culminated in the laying of more wreaths and the reinstatement of Bhambatha to his chieftaincy at Mpanza on 11 June.

The latter affair also engaged the national government, and the crowded programme included speeches by the president and deputy president, as well as provincial premier, the chairperson of the House of Traditional Leaders and the king of the Zulu nation. A special postage stamp was issued to mark the occasion. Almost a week later, on 16 June or Youth

\footnotetext{
${ }^{76}$ It has also been called the Natal Rebellion, the Natal Native Rebellion, the Poll Tax Rebellion, the Poll Tax Uprising, the Zulu Uprising, and the War of the Heads.
} 
Day, a Bhambatha Memorial Concert took place at Lake Merthley, also near Greytown. ${ }^{77}$ On 27 September Bhambatha was awarded the national Order of Mendi in Gold for Bravery. ${ }^{78}$

Outside the government sphere there was very little to mark the centenary. Two plays, which did not enjoy government support, hardly got off the ground. ${ }^{79}$ A third, which did, was the musical 1906 Bhambada-The Freedom Fighter, which ran for a fortnight in Pietermaritzburg, and was touted to go on to Pretoria, but did not, probably for political as well as aesthetic reasons. ${ }^{80}$ A government-funded Indigenous Knowledge Systems project by local university academics produced a book entitled Freedom Sown in Blood: Memories of the Impi Yamakhanda, which contained practically nothing about the rebellion itself. ${ }^{81}$ Another book, Remembering the Rebellion: The Zulu Uprising of 1906, comprised a series of twelve commemorative supplements previously published in the The Witness and related newspapers in partnership with the provincial department of education. Beautifully illustrated and pitched at schools, it necessarily simplified scholarship on the rebellion for its readers. $^{82}$

\footnotetext{
${ }^{77}$ Among the more informative public statements are: KwaZulu-Natal Provincial Government and Republic of South Africa, Department of Arts and Culture, Age of Hope: Through Struggle to Freedom: Saluting our Heroes. Reinstating Inkosi Bhambatha (Pietermaritzburg, Office of the Premier, 2006); KwaZulu-Natal, Office of the Premier, Bhambatha Centenary Committee, Saluting our Heroes and Celebrating our Rich Heritage in KwaZulu-Natal 2006 (Pietermaritzburg, Office of the Premier, 2006); KwaZulu-Natal Celebrating Youth Heroism \& Activism 2006 (Pietermaritzburg: Office of the Premier and Youth Commission, 2006); The Daily News, "Bhambatha reinstated", 9 June 2006; and The Witness, "100 Years of Bhambatha Poll Tax Uprising" [advertisement], 15 June 2006. See also the press reports in the Ilovu News, "Old Enemies Bring Closure to the Past in Richmond", April 2006; and The Witness, "Bhambatha Reinstated", 6 February 2006; "Memorial Reconciles", 24 April 2006; "SA Post Office to issue Bhambatha Rebellion Stamp", 26 May 2006; "Preparations Fit for an Inkosi", 6 June 2006; "Mbeki Hails Great Hero Bhambatha", 12 June 2006; Witness Echo, "Comrades, Hands off June 16", 19 June 2006 and "Youth gets into Parliament", 22 June 2006; and The Sowetan, "Rivals Stand United", 12 June 2006. Several activities based upon ambitions of various local groups and scheduled early on appear not to have transpired; see the Bhambatha Centenary Committee's Saluting Our Heroes and "Khandampondo 1906-2006" (7 page typescript, [April] 2006); and Office of the Premier, "Saluting our Heroes and Celebrating our Rich Heritage in KwaZulu-Natal", supplement in The Sunday Tribune 24 September 2006 and The Mercury 25 September 2006.

${ }^{78}$ The Witness, "Mbeki Honours KZN's Greatest with National Orders", 27 September 2006.

${ }^{79}$ See The Mercury, Goodlife supplement, "War, Song and Dance", 10 November 2006, and "Out of Africa", 15 December 2006; The Witness, "Bhambatha Musical Celebrates the Centenary of the Uprisings", 30 March 2006; and Witness Echo, "Musical about Love and War", 21 December 2006.

${ }^{80}$ See and cf. The Mercury, "Premier's Office Spent R7m on Bhambatha Play", 23 February 2007; The Sunday Tribune, "Bhambatha Cash Bonanza", 11 June 2006; and The Witness, "The Long Journey of Stroppy Ngema", 11 November 2006; "Edutainment at Winston [sic] Theatre", 16 November 2006; "When Drama, Dance Obscure the Facts", 2 December 2006; "Ngema's Piece of Singing, Dancing History", 5 December 2006.

${ }^{81}$ Thenjiwe Magwaza, Yonah Seleti, and Mpilo Pearl Sithole, eds., Freedom Sown in Blood: Memories of the Impi Yamakhanda: An Indigenous Knowledge Systems Perspective (Thohoyondou: Ditlou, 2006).

${ }^{82}$ Jeff Guy, Remembering the Rebellion: The Zulu Uprising of 1906 (Pietermaritzburg: University of KwaZuluNatal Press, 2006). See The Witness, "Premier Launches Bhambatha Rebellion Centenary Year", 16 March 2006, and the twelve supplements which appeared 16 March - 13 July 2006.
} 
The events and productions of the centenary, reflecting the interests of the current dispensation, glorified Bhambatha, but added little, in an academic sense, to a real understanding of the rebellion. The rebellion has been characterized as the opening shot of the South African struggle for liberation from colonialism, imperialism and apartheid, and Bhambatha as the torchbearer of the movement. ${ }^{83}$ It is remarkable that an event, now officially described as an important watershed in South African history, has received so little scholarly attention. ${ }^{84}$ Indeed relatively little had been written and published about it and few works were generally available at the time of the centenary. ${ }^{85}$ This deficiency may account

\footnotetext{
${ }^{83}$ See and cf. The Mercury, "Mbeki, Zuma share the stage", 12 June 2006, and "A common tryst with destiny", 5 October 2006; The Sowetan, "Rivals stand united", 12 June 2006; Umphithi [Msunduzi Municipality newspaper], "Premier Upbeat about KwaZulu-Natal", February 2006; The Witness, "An Event to Remember", 16 March 2006; "Rewriting History", 27 March 2006 and "Remembering the Bhambatha Rebellion", 10 April 2006.

${ }^{84}$ Notably falling through the cracks was the provincial government's International Bhambatha Colloquium to be held in October 2006, in partnership with the national Department of Arts and Culture.

${ }^{85}$ The books by Stuart and Marks (see below) have long been out of print, as are Walter Bosman, The Natal Rebellion of 1906 (London and Cape Town: Longmans, Green, and C. T. Juta, 1907) and C. T. Binns, Dinuzulu: The Death of the House of Shaka (London: Longmans, 1968). The printed documents were, of course, once-off publications: see Colony of Natal, The Natal Native Rebellion as Told in Official Despatches from January $1^{\text {st }}$ to June $23^{\text {rd }}, 1906$ (Pietermaritzburg: Davis, 1906)-cited hereafter as $O D$-and also printed in The Natal Government Gazette, No. 3568A, 2 October 1906; Report of Native Affairs Commission 1906-7 and the accompanying Evidence (Pietermaritzburg, Davis, 1907); and The Trial of Dinuzulu on Charges of High Treason at Greytown, Natal, 1908-09 (Pietermaritzburg: "Times", 1910). Lars Berge, The Bambatha Watershed: Swedish Missionaries, African Churches and an Evolving Church in Rural Natal and Zululand 1902-1910 (Uppsala: Swedish Institute of Missionary Research, 2000), is tangential and has little on the rebellion itself, and Andreas Z. Zungu, uSukabhekuluma and the Bhambatha Rebellion (translated from the 1933 edition by A. C. T. Mayekiso, Durban: CSSALL, 1997) is an entertaining mix of reminiscence and imagination. Neither seems to have enjoyed wide circulation. Similarly, P. S. Thompson, An Historical Atlas of the Zulu Rebellion of 1906 (Pietermaritzburg: 2001); Bambatha at Mpanza: The Making of a Rebel (Pietermaritzburg: 2004); and Incident at Trewirgie: First Shots of the Zulu Rebellion 1906 (Pietermaritzburg, 2005), are private publications and rank as samizdat. The books by Benedict Carton and John Lambert are discussed below. There were a fair number of articles on the subject, although they appeared in academic or parochial journals with limited circulations. Benjamin Colenbrander, "An Account of the Zulu Rebellion of 1906", Natalia 35, 2005, 10-28, is the report of the Magistrate of the Nkandhla Division in Zululand. The currently accepted spelling is Nkandla. Deriving from her book Reluctant Rebellion: The 1906-1908 Disturbances in Natal (Oxford: Clarendon Press, 1970) are Shula Marks's, "Class, Ideology and the Bambatha Rebellion", in Banditry, Rebellion and Social Protest in Africa, ed. Donald Crummey (London: Currey, 1986), 351-72, and "The Zulu Disturbances in Natal", in Protest and Power in Black Africa, eds. Robert I. Rotberg and Ali A. Mazrui (New York: Oxford University Press, 1970), 213-57. See also Ken Gillings, "The Bambata Rebellion of 1906: Nkandla Operations and the Battle of Mome Gorge, 10 June 1906", Military History Journal 8, no. 1, June 1989, 21-31, and "The 'death' of Bhambatha Zondi: A Recent Discovery", Military History Journal 12, no. 4, December 2002, 133-37; Sean Redding, "A Blood-Stained Tax: Poll Tax and the Bambatha Rebellion in South Africa", African Studies Review 43, no. 2, September 2000, 29-54; and P. S. Thompson, "Isandlwana to Mome: Zulu Experience in Overt Resistance to Colonial Rule", Soldiers of the Queen 77, June 1994, 11-15; "Bambatha's Personal Rebellion", Natalia 33, 2003, 59-66; "Bambatha's Rebels: a Profile-Age, Faction, Motive", Historia 48, no. 2, November 2003, 98-108; and "The Zulu Rebellion of 1906: The Collusion of Bambatha and Dinuzulu", International Journal of African Historical Studies 36, no. 3, 2003, 533-57.
} 
in part for the disagreement over what to name the rebellion, if indeed it was a rebellion, ${ }^{86}$ and even how to spell Bhambatha's name. ${ }^{87}$

The chronology of events is well known. First, in February and March 1906, there was a bloody incident between police and poll tax protesters followed by a repressive militia demonstration in the southern part of the colony. Second, there was Bhambatha's rebellion at Mpanza in April, which moved to the Nkandla district in Zululand and flourished until it was crushed by militia early in June. Third, late in June there was a disorganized uprising among several chieftaincies in the Maphumulo district which the militia suppressed in July.

It is generally agreed that the immediate cause of the rebellion was the government's attempt to collect the new poll tax of $£ 1$ on all adult males (with the exemption of certain important categories), which fell most heavily on the indigenous population in a period of economic depression. Yet beyond this there is disagreement over basic or underlying factors. James Stuart, a participant, saw an inevitable clash between civilization and savagery. ${ }^{88}$ Shula Marks, writing almost sixty years afterwards, saw in it the complexities of secondary resistance to colonialism, ${ }^{89}$ and John Lambert, Benedict Carton, Sean Redding, and Jeff Guy, while focusing on particular aspects have written within the same ambit twenty-some years later. $^{90}$

\section{James Stuart's History of Bhambatha's Rebellion}

\footnotetext{
${ }^{86}$ Mpilo Pearl Sithole, “'Rebellion' or Uprising?: A Reinterpretation of Impi Yamakhanda”, in Freedom Sown in Blood, chapter 4.

${ }^{87}$ The spelling has changed in conformance with changes in Zulu orthography and thus Bambata, Bambatha, and Bhambatha, paralleled by Bambada and Bhambada, and latterly even Bhambhata and Bhambhatha.

${ }^{88}$ James Stuart, A History of the Zulu Rebellion 1906 and of Dinuzulu's Arrest, Trial and Expatriation (London: Macmillan, 1913), 517.

${ }^{89}$ Marks, Reluctant Rebellion: The 1906-1908 Disturbances in Natal, xviii-xxv.

${ }^{90}$ John Lambert, Betrayed Trust: Africans and the State in Colonial Natal (Pietermaritzburg: University of Natal Press, 1995) describes the progressive extension and abuse of power by the colonial state, which, combined with natural disasters, were undermining as well as reshaping traditional African society, so that a violent reaction of some sort seemed practically inevitable. Benedict Carton, Blood from Your Children: The Colonial Origins of Generational Conflict in South Africa (Pietermaritzburg: University of Natal Press, and Charlottesville: University Press of Virginia, 2000) focuses on the younger generations' challenging patriarchal authority in changed economic circumstances, which culminated in the rebellion. Sean Redding, "Governing the Zulu by Killing Them: Poll Tax and the Bambatha Rebellion in Natal and Zululand", chapter 4 in Sorcery and Sovereignty: Taxation, Power, and Rebellion in South Africa, 1880-1963 (Athens, Ohio: Ohio University Press, 2006), looks at the ways in which the rebels conceptualized and justified their acts in accordance with traditional religious beliefs. In addition to Remembering the Rebellion Jeff Guy is also the author of The Maphumulo Uprising: War, Law and Ritual in the Zulu Rebellion (Pietermaritzburg: University of KwaZuluNatal Press, 2005), which trains more narrowly on a group of chieftaincies in the coastal district which were peculiarly susceptible to rebellion because of their internal problems.
} 
Little of a factual nature was known about Bhambatha. At the time of the centenary the only credible biographical source was James Stuart's History of the Zulu Rebellion, published in 1913. Stuart was a civil servant and Zulu linguist who had held a number of magisterial posts. He was an intelligence officer in the militia during the rebellion. Much of his information came from personal acquaintance with those who knew Bhambatha and who had been directly involved in the rebellion. He was Secretary of the Native Affairs Commission which in 1906-1907 sought out the causes of the rebellion and proposed a remedy of grievances. He had access to military reports. He was involved in the preliminaries of Dinuzulu's treason trial and took statements from Bhambatha's wife, Siyekiwe, and others. ${ }^{91}$

Stuart's account of Bhambatha is sympathetic, but never approving. His Bhambatha is a driven man and an irresponsible chief, vicious in habits and volatile in disposition, deeply in debt to landlords and distrusted by the government. "A more perturbed spirit than he was at the close of 1905 it is scarcely possible to conceive". Bhambatha was deposed as chief by the government, not for leading his people to resist the poll tax, but for failing to report, as was his duty, a group of them which had armed to resist it - and which he had dissuaded from doing so! Summoned to explain himself, he escaped arrest, and fled to Zululand with his favourite wife and three children. He was already bent on rebellion, and

\footnotetext{
${ }^{91}$ Stuart is perhaps better known today for his collection of information, which has recently been published in Colin B. Webb and John B. Wright, eds. The James Stuart Archives of Recorded Oral Evidence Relating to the History of the Zulu and Neighbouring Peoples, 6 vols. (Pietermaritzburg, University of Natal Press, 19762001). Stuart's career in the colonial civil service is given in the Colony of Natal, Natal Civil Service List, 1909 (Pietermaritzburg, Davis, 1909), 232. Shortly after the outbreak of the rebellion he was seconded to Greytown as Intelligence Officer and made a daring trip (21-23 April) to the Nkandla magistracy in the company of Funizwe and others for the purpose of identifying Bhambatha when Bhambatha's capture seemed imminent (Stuart, Zulu Rebellion, 258). He remained at the magistracy until early May when he returned to Natal and was attached with Colonel Mackay's column, which operated in the Umsinga and Nqutu divisions. In his report Mackay states: "Capt. Stuart rendered invaluable assistance to my column as Intelligence Officer. He was indefatigable in the prosecution of his enquiries and his information was invariably correct, and absolutely to be depended [upon]. His most extreme knowledge of natives, their history, habits, customs, and language peculiarly fitted him for such a position. Should an Intelligence Officer be appointed to the permanent staff no more suitable officer could be found for the work". See Colonial Secretary's Office (CSO) 2599 C147/1906. Sir Charles Saunders, then Commissioner for Native Affairs in Zululand, was not quite so generous. He wrote to the magistrate at Nqutu just after Mome: "I saw a good deal of James Stuart, and quite agree with your opinion about him. I found exactly the same in all I had to do with him at Nkandhla; as you say, he is a very good chap, but I think this business is a little beyond him". (Saunders to C. Hignett, 14 June 1906, in the Archives of Zululand-hereafter ZA 28). For Stuart's appointment as a secretary of the Natal Native Affairs Commission, see Report of the Native Affairs Commission 1906-7, 54; and for his access to military reports, "List of Official Papers Returned to Under Secretary for Defence, Pretoria, by Capt. J. Stuart, N.F.A. on 7 June 1913", in CSO, 2599 C147/1906. The depositions are in the records of the Attorney General's Office (AGO) I/7/61. All official documents are in the Pietermaritzburg repository of the KwaZulu-Natal Archives, unless otherwise stated.
} 
apparently was called to the Osuthu by Dinuzulu and was given a Mauser rifle and told him to go back to Natal and start the rebellion. Accompanied by two escorts from Usuthu he did just that. He reclaimed his chieftaincy by force, attacked the magistrate and then the police, but finding no support among his fellow chiefs, he escaped capture again and fled to Zululand with his following. Here he found sanctuary in the Nkandla forest under the protection of the aged chief Sigananda. Sigananda accepted him as Dinuzulu's man, and joined the rebellion, bringing over most of his own tribe and many from others. Bhambatha was a leader of importance in the rebel army until the battle of Bhobe, at which his special medicine to deflect white men's bullets proved ineffectual. He later visited Usuthu in the company of the rebel leader Mangathi and had another interview with Dinuzulu, after which he rejoined the rebels, and soon afterwards was killed along with many others in action at the Mhome Gorge. He could have saved himself and his men by heeding reports of imminent entrapment by the militia, but he did not. ${ }^{92}$

\section{A New History, based on the Colonial Records}

Stuart's biography describes Bhambatha's career in detail up to and including the outbreak of the rebellion, but it is relatively sketchy on it afterwards. ${ }^{93}$ In its broad outline and many of its details Stuart's biography of Bhambatha still appears to be correct, but since Stuart's time many official documents concerning Bhambatha in the rebellion which were not accessible to him have become accessible to the public in the Pietermaritzburg repository of the KwaZuluNatal Archives. Shula Marks made good use of them, and, since she wrote, still more have become available.

Today's scholar can assay a new biography of Bhambatha, and the purpose of this article is to do just that. The biography which follows supersedes Stuart's, but only in part. It adds to and corrects parts of his account, but largely confirms and incorporates much of his information. The thesis is that Bhambatha was not a strong leader, but in fact a weak one,

\footnotetext{
92 See Stuart, Zulu Rebellion, 157-97 passim, and 202, 212, 228, 235-37, 310, 313. The quotation is on 159. The term "tribe" is a contemporary term which cannot be dispensed with in this context.

${ }_{93}$ The citations in the preceding note after passim are the only ones which pertain to Bhambatha's career from late April to early June 1906. When Mackay's column left the Nkandla magistracy on 11 May Stuart was removed from the theatre in which Bhambatha operated.
} 
who had to be looked after (or "managed") much of the time by stronger personalities such as Sukabhekuluma and Mangathi. The enemy spoke of "Bhambatha's rebellion" and used his name to identify all manner of agents in the course of operations; but in truth Bhambatha exercised practically no control over operations at all. His glorification today is a great irony.

Official records pertaining to the rebellion are plentiful and yield a variety of evidence, some of it quite conflicting. What motivates one chief to rebel, another to stand by the government, and yet another to "chew with both jaws"? What is the role of the Zulu king Dinuzulu, who appears to support both sides, albeit in different ways at different times? There is no agreement in the evidence, which is off-putting for those, such as the politicians of the centenary who want to know the mainspring of rebellion and to categorize men and their deeds simply and easily.

This account of Bhambatha's career is based upon colonial sources, i.e. the writings and publications of whites in the Colony of Natal bearing on and usually contemporary with the relevant events. For the most part they were recorded by government and military authorities, and are based on observations, direct and indirect reports, and hearsay (as in the case of the James Stuart Archive). The colonial records comprise official correspondence and reports of all sorts, newspaper reports, legal declarations and statements, diaries and journals, and trial records. Contemporary records are often better for dating and placing events. Subsequent records often afford more analysis and detail. While, of course, colonial records may be considered vitiated by their very character, their bias does not necessarily mean they cannot be accurate. The men who wrote them usually were motivated by a desire to know what was actually happening so that they could act accordingly, and they would defeat their own purposes by deliberately covering up or distorting events. There are instances of their misunderstanding and misinterpreting events, but rarely of their dissembling.

There is a significant difference between court and other records. Objective truth is subordinated to a partisan quest for a verdict. In this article much use is made of the records of the trials of the so-called rebels - courts martial and magistrates' courts trials under martial law, and, of course, the Special Court which tried Dinuzulu (and Sukabhekuluma) for high treason. ${ }^{94}$ The character and value of the evidence vary greatly in all these sources. Jeff

\footnotetext{
${ }^{94}$ The official documents pertaining to and the transcripts of the trials of Dinuzulu and Sukabhekuluma (called Cakijana in these cases), 1908-1909 appear in the records of the Registrar of the Supreme Court (RSC) III/3,
} 
Guy has pointed this out very well in respect of those he used for The Maphumulo Uprising, although he is rather too severe in his strictures on colonial bona fides and methods. ${ }^{95}$ In any case, the selection and evaluation of evidence from these sources depend on the knowledge, experience and judgement of the investigating scholar. Does he prefer the word of the prosecution or of the defence in a given instance? What is to be made of absolutely contradictory statements, such as appear in Rex vs Dinuzulu? The evidence has to be sifted, compared, weighed, and set against other evidence from outside the court. It will be argued that the scholar's own bias will come into play. Indeed, it will, but so should the scholar's self-awareness allow for its correction.

\section{An Alternative History, Based on Indigenous Orality}

The critical reader who thinks that Bhambatha and the rebellion will be misrepresented through the use of colonial records naturally will want to know what alternative records are available which would redress the balance of perspective. These alternative records consist almost entirely of the reports of persons who lived at the time of the rebellion or heard about it from those who did, some of whom were participants. These have been transmitted by word of mouth, and therefore may be categorized as Oral History. Many historical records have their origins in oral history, but once recorded they become subject to a different methodological scrutiny.

Oral history is closely allied to, indeed, may be considered an adjunct to Indigenous Knowledge Systems (IKS), which seek in part to divorce the vitiating European or colonial influences. IKS is very popular with scholars seeking an alternative to colonial documents, but the collection of oral history has not always embraced the same methodology required for documentary history. In order to be usable it must be written down, and so it finally becomes susceptible to that methodological rigour.

The Special Court: Zulu Rebellion, and AGO I/7/51-81, "Zulu Rebellion". The records of the courts martial appear in Secretary of Native Affairs (SNA) I/6/26-28, Native Rebellion, 1906: Court Martial Proceedings. The records of trials under martial law appear in the martial law case books, variously entitled, in the archives of the magistrates, most notably in this instance $1 / \mathrm{GTN} 1 / 3 / 2 / 1,1 / \mathrm{KRK} 1 / 4 / 1 / 1$, and 1/NKA 1/5/1/1-2, for Greytown, Kranskop and Nkandla, respectively. All these documents are in the Pietermaritzburg Archives Repository.

${ }^{95}$ Guy, The Maphumulo Uprising, 119-26. 
Court records may be regarded as a type of oral history, which is recorded as soon as possible and therefore is very useful; but sometimes the recording of oral history comes too late. In the collection of the Oral History Project (1983) at the Killie Campbell Africana Library are six interviews with old men who speak of the rebellion with some personal knowledge. Some of them tell interesting stories, but they are fantastic and cannot be correlated with contemporary documentation.

There are two publications (apart from Stuart's) of oral history which do have an important bearing on Bhambatha. Magema Fuze's The Black People and Whence They Came: A Zulu View, originally published in 1922, contains three chapters (64-66) on Bhambatha and the rebellion. ${ }^{96}$ The information evidently comes from contemporary but unidentified informants, and unfortunately it is badly organized and the account is confused. Andreas Zungu's USukabhekuluma and the Bhambatha Rebellion, originally published in 1933, records the reminiscences of Sukabhekuluma a quarter of a century afterwards. ${ }^{97}$ There is a wealth of detail in the fast-paced narrative, but much of it is obviously distorted and incorrect, which casts doubt on the rest. The scholar must make reference to the reminiscences, but cannot place much reliance on them. The critical reader would do well to compare it with the consolidated statements of Sukabhekuluma taken at Kranskop in May $1908 .^{98}$

The most important recent work using oral history is Freedom Sown in Blood: Memories of the Impi Yamakhanda: An Indigenous Knowledge System Perspective edited by Thenjiwe Magwaza, Yonah Seleti and Mpilo Pearl Sithole. This is the fruit of an IKS project at Ngome in 2003-2005. It contains some interesting material, but scarcely anything about the rebellion itself. In this respect it represents a missed opportunity. Intensive interviews with seventeen men who talked about the rebellion are omitted (and the author has not been able to find out where the transcripts are). There is a contentious genealogy of Bhambatha, but otherwise little is said about him. The book does contain extracts from three izibongo (praise songs), two apparently recorded by James Stuart and Andreas Zungu some time ago,

\footnotetext{
${ }^{96}$ Magema Fuze, The Black People and Whence They Came: A Zulu View, translated by H. C. Lugg and edited by A. T. Cope (Pietermaritzburg: University of Natal Press and Killie Campbell Africana Library: 1979). The first edition was published in 1922.

${ }_{97}$ Andreas Zungu, USukabhekuluma and the Bhambatha Rebellion, translated by A. C. T. Mayekiso (Durban: CSSALL, 1997). First edition: 1933.

${ }^{98}$ This appears in AGO I/7/68, "Resume", 20 May 1908.
} 
and the third during the project by the present Zondi imbongi Ngoni Ndlovu. (It is curious that another isibongo, in Zungu's book, which is more like Stuart's in content and quite different from the one in Magwaza et al, has been omitted.) The three izibongo give more or less the same information and this approximates (but only approximates) attested information in colonial records. They do not make up a particularly flattering biography of Bhambatha. They mention his swiftness as a runner, his viciousness in hitting people with a stick, his taking cattle from white farmers, and his being at odds with chiefs loyal to the government. Zungu and Ndlovu mention his being summoned by the authorities to Greytown, the immunizing medicine and the fight with the police, his flight to Zululand, and, oddly, his desire to return to Natal and his followers' refusal to do so, and his escape to Mozambique. This is the best we get from oral history here. There is nothing that fundamentally contradicts a colonial-based account, except the later accretion about escaping to Mozambique.

There are also cases of writers of fiction who claim to make use of oral history. The problems with telling a good story are illuminated in several chapters of the recently published Zulu Identities: Being Zulu, Past and Present. ${ }^{99}$ In this 2008 publication, Dan Wylie (chapter 7) and John Wright (chapter 6) have little use for such fictive truth, whereas Sifiso Ndlovu is more accommodating (chapters 9 and 10), while Jabulani Sithole (chapter 27) and Nsizwa Dlamini (chapter 32) appear to occupy an intermediate position. Whatever gems of fact may be embedded in Rolfes Dhlomo's Dinuzulu kaCetshwayo (1968) and Elliot Zondi's Insumansumane (1986), these works are still fiction. ${ }^{100}$ Similarly the centenary plays. Historical fiction does depend on some historical fact, but it is derivative, and for that reason it is untrustworthy as a source.

The critical reader will gather from the above that the alternative sources are not sufficient to provide a detailed history of Bhambatha's career or the rebellion. The centenarists who have glorified Bhambatha have done so in a few words. If they rely on the alternative history they cannot do otherwise. Only the colonial records provide a coherent, detailed narrative.

\footnotetext{
99 Benedict Carton, John Laband and Jabulani Sithole, eds., Zulu Identities: Being Zulu, Past and Present (Pietermaritzburg, University of KwaZulu-Natal Press, 2008).

100 Rolfes Dhlomo, Dinuzulu kaCetshwayo (Pietermaritzburg, Shuter \& Shooter, 1968) and Elliot Zondi, Insumansumane (Johannesburg, Witwatersrand University Press, 1986).
} 


\section{The Troubled Chief}

Bhambatha was born circa 1865, the son of Mancinza (also called Sobhuza) kaJangeni by his chief wife. Mancinza was the chief of the Zondi tribe and resided with the branch of it at Ngome, in that part of the Colony of Natal demarcated as the Umvoti Division. Mancinza died in 1883, and his brothers Zikwazi and Magwababa were successive regents for his son Bhambatha, who acceded to the chieftaincy in 1890, when he was deemed of age by both the tribal elders and the colonial government. Any leader would have found the Ngome chieftaincy challenging. The people lived on farms owned chiefly by Boer settlers. The population grew, but their agricultural techniques remained limited. They struggled to pay their rents and fell into poverty. Rinderpest and the South African War added to their misery. It is not clear from the records whether or not members working off their location provided sufficient income to ease the situation. Bhambatha sought in vain to get more land for his people by making claims on that of the neighbouring Bomvu tribe. Early in the war he claimed the Boer landlords were disloyal and were trying to evict his people because they were loyal to the Crown. In 1902 and again in 1905 he asked the government if his people could be relocated to Zululand. ${ }^{101}$

Like his father, Bhambatha had a chequered career in marriage. His first wife, Mamqayana, bore him three children, but they parted after she committed adultery. His second wife, Magogotshwana, left him. He sought a third wife, but could not afford the bride price; they were not married, though she bore him a son, who was later murdered. Finally he married a twin against the elders' advice. This was Masikonyana, better known in the

101 Thompson, Bambatha at Mpanza, 8-16 passim; cf. Stuart, Zulu Rebellion, 157-59 and Marks, Reluctant Rebellion, 201. These three books, which are all out of print and of limited availability (only 200 copies of Thompson's were printed, of which a third went to provincial school libraries), cover the background and outbreak of the rebellion at Mpanza in varying detail and perspective. Because of this relative inaccessibility their common story of the outbreak is given at greater length here than otherwise would be warranted. Also, they are referred to separately in the notes for convenience of comparison. (In this and notes for this and the next two sections, the three sources are contradistinguished by "cf." in order, for the convenience of the reader, to indicate the "new" and "old" information.) On genealogy see "Bhambatha's Family Tree: Oral evidence, new and old" in Natalia, 38 (December), 2008. On landlords and evictions see Johan Wassermann, "Sowing the Seeds of Rebellion': Chief Bhambatha kaMancinza and the Anglo-Boer War, 1899-1902", African Historical Review 39, no. 2, 2007, 91-106. According to the 1904 census the abaseNgome had 1547 males and 850 huts. It was of medium size demographically, the third largest tribe in the division, although it had only half the number of men of the largest tribe in the division. It was dwarfed by comparison with the largest tribes in Natal and Zululand, e.g. the amaChunu in the Weenen and amaChube in the Nkandla divisions. See Colony of Natal, Census of the Colony of Natal April, 1904 (Pietermaritzburg: Davis, 1905), 281; and cf. Ministerial Department of Native Affairs, Blue Book on Native Affairs, 1904 (Pietermaritzburg, "Times”, 1904), 147-48. 
literature as Siyekiwe, by whom he had two children. She was his favourite wife. She was pregnant again in late 1905, and he had a homestead (which he called "the place of the spear") constructed just for the two of them. Her children were sent to her father's place and the three children of his first wife were brought to attend them. ${ }^{102}$

Bhambatha was also plagued by money difficulties. He was a party in thirty-six cases for debt, although he seems to have appeared in court in only about half of them. He was imprisoned briefly in 1892, and suspended as chief on charges of cattle stealing in 18941895, but got off when several witnesses perjured themselves. He was fined for cruelty to animals in 1896. In 1902 he was gravely ill, and in 1903 spent a long time with his uncle Nongamulana, the chief of the amaZondi living in the Nkandhla Division. After the war he was imprisoned for short periods four times for debt. He was fined for seduction, trespass, contempt of court, and not removing burr weed. He was reprimanded by the magistrate for failing to take action to prevent two faction fights, and there probably were many more which he did not prevent, and in August 1905 he was a leading participant in one, in which he struck down several men with his stick and ordered his followers to "finish" them. This was the last straw for the magistrate and for the department of Native Affairs. No other chief had such a bad record. The government decided to depose him as chief. The Governor signed the order on 23 February 1906.

The abaseNgome had two or three factions. One lived in the Mpanza valley, and they supported Bhambatha through thick and thin. Another lived in the Loza valley, and they looked to Bhambatha's uncle, Magwababa, who had been regent during his minority. The possible third faction, about which little is known, lived in the Nsundu valley to the East. ${ }^{103}$

Bhambatha did not lead his people to resist the poll tax, although he and they, like all the other Africans in the Colony, bitterly resented it. It was a portion of the Mpanza faction that armed and headed towards Greytown with a view to defy (and quite possibly to attack) the magistrate on 22 February. Bhambatha headed them off and persuaded them not to, and they went home; but they got close enough to Greytown for a rumour to spread that Bhambatha and his men were going to attack the town that night. There was a scare and the settler community went into laager against an attack. Bhambatha should have reported what

\footnotetext{
102 Thompson, Bambatha at Mpanza, 16-17. Cf. Stuart, Zulu Rebellion, 158.

103 Thompson, Bambatha at Mpanza, 11-12, 15-17, 20-25, 44; and "Bambatha's Personal Rebellion", 61-62. Cf. Stuart, Zulu Rebellion, 159-60, and Marks, Reluctant Rebellion, 202.
} 
the Mpanza men had done, but he did not. The government had already decided to depose him, but they wanted an explanation of this latest development as well. They were sensitive to legal niceties, perhaps the more so because the Colony was under martial law as a result of the incident near Richmond. Bhambatha was summoned to Pietermaritzburg. He was promised safe passage, but Bhambatha and his supporters did not trust the government. He said he would go, then, persuaded by Mpanza men, he decided not to go. A detachment of police and militia went to get him on 9 March, but he eluded them. ${ }^{104}$

\section{Recourse to Dinuzulu}

At this juncture Bhambatha went to the Osuthu, the great place of the Usuthu chief Dinuzulu kaCetshwayo. Dinuzulu was widely regarded and treated as the king in Zululand and as such respected in Natal as well. Indeed, he had been king until he resisted British annexation of Zululand in 1888, and for his "rebellion" against the British crown he had been deposed and exiled to St. Helena. He had returned ten years later as part of the agreement by which Zululand was annexed as a province to the Colony of Natal, but officially he was only the chief of the Usuthu tribe, in the Ndwandwe Division. In so far as the colonial authorities let him, because they could not really stop him, he assumed a regal posture socially if not politically. He received fealty from many of his former subjects, and may well have nurtured ambitions to retrieve his former glory. Rumours circulated of his restoration and the extirpation of the settler regime, especially just prior to the rebellion. Yet he set an example of loyalty by having his own people pay the poll tax early. ${ }^{105}$

Why did Bhambatha go to Dinuzulu? According to Dinuzulu he came unbidden to ask for a place to live, free of the impositions of white landlords. This Dinuzulu could not give him, and sent him home. As he was about to leave, Bhambatha saw that Dinuzulu was ill, and said that his tribe had a great doctor who could cure him. Dinuzulu arranged to have two men accompany Bhambatha back to Natal in order to fetch this doctor. ${ }^{106} \mathrm{He}$ had a ready explanation for Bhambatha's unseemly behaviour after he left the Osuthu: Bhambatha was

104 Thompson, Bambatha at Mpanza, 27-52 passim, and "Bambatha’s Personal Rebellion", 60-61. Cf. Stuart, Zulu Rebellion, 161-66, and Marks, Reluctant Rebellion, 203-04.

105 Thompson, Bambatha at Mpanza, 55-56, and "Bambatha's Personal Rebellion", 59-60. Cf. Stuart, Zulu Rebellion, 109-118. For Dinuzulu's career after 1884, especially see Marks, Reluctant Rebellion, 89-116. 
mad. ${ }^{107}$ According to Bhambatha's wife and children he was summoned to the Osuthu by one of these men. He did want a place to live, but he did not get it. Instead Dinuzulu gave him a Mauser rifle and told him to return to Natal and start a rebellion, and promised support after it got started. ${ }^{108}$ Dinuzulu, of course, denied this. The two accounts are irreconcilable. ${ }^{109}$ According to Mangathi (of whom more below) Bhambatha also told Dinuzulu that his tribe also had medicine handed down from his forefathers that would repel the white man's bullets, and that many other chiefs in Natal were prepared to join him in rebellion. ${ }^{110}$

It is remarkable that Bhambatha, a petty chief in Natal, dared to go to the most august personage in Zululand; ${ }^{111}$ more remarkable that he would go to the Osuthu without a guide, ${ }^{112}$ and take along his pregnant wife and three children, whom he left there. Moreover Bhambatha did return home with a Mauser, and two other rifles, which he had not taken with him, and Dinuzulu would have us believe he picked them up somewhere on his way back. ${ }^{113}$ Nor did the great doctor materialize. A lesser one was taken back by one of Dinuzulu's men. Dinuzulu would have nothing to do with the man, whose body was found several weeks later between the Osuthu and Mpanza. ${ }^{114}$

${ }^{106}$ Thompson, Bambatha at Mpanza, 63-73 passim; "Bambatha's Personal Rebellion", 62; and "Collusion of Bambatha and Dinuzulu", 540, 551-52. Cf. Marks, Reluctant Rebellion, 281, 283-84.

107 Thompson, Bambatha at Mpanza, 74. Also, see and cf. the statement of Mankulumana, 27 April 1906, in AGO I/7/68 and in the records of the Prime Minister (PM) 59 463/1906, and the depositions of Ngqengqengqe, dated 26 March 1908 in AGO I/7/78 and 27 April 1908 in AGO I/7/70 and 1/7/79.

${ }_{108}$ Thompson, Bambatha at Mpanza, 64-73 passim, and see also 15 and 58; "Bambatha's Personal Rebellion", 62, and "Collusion of Bambatha and Dinuzulu", 541, 550-51. Cf. Stuart, Zulu Rebellion, 166-167, 433-34; and Marks, Reluctant Rebellion, 280-81, who sides with the Court and blames Stuart for perpetuating a falsehood.

${ }^{109}$ It will be observed in notes 30 and 32 that the same pages are cited "passim" in Bambatha at Mpanza, which is because the irreconcilable accounts are juxtaposed in parallel columns.

${ }^{110}$ Thompson, Bambatha at Mpanza, 75. Cf. statement of Mangathi, 18 December 1907 in the records of the Lieutenant Governor and Governor of Natal (GH) 1462, and SNA I/6/29 and AGO I/7/68: "Resume of statement made by CAKIJANA at Krantzkop, on 20th May 1908 immediately prior to the reading over to him of the statement made by him and taken down by Mr J. S. Hedges". The latter document (cited hereafter as Cakijana, "Resume") is one of the most important sources of information on Bhambatha's rebellion.

${ }^{111}$ A unique hypothesis is that of Ingrid Mary Perrett, "Dinuzulu and the Bambata Rebellion" (M.A. thesis, University of Natal, 1960): "That the Rebellion was the result of a general rebellious spirit, and that Dinuzulu took advantage of the unrest, encouraged the rebels and supported them in an attempt top gain concessions and appointment as Paramount Chief". It is based on documents in the SNA, and Bhambatha is only one of many with whom Dinuzulu was in contact.

${ }^{112}$ Siyikiwe said that Bhambatha had made Dinuzulu's acquaintance at the latter's homestead Nobamba shortly before the South African War, when Bhambatha was searching for an errant sister and her lover, and that Dinuzulu's messenger Ngqengqengqe was their guide for most of the way in Zululand (Bambatha at Mpanza, 56-57).

${ }^{113}$ Thompson, Bambatha at Mpanza, 74-75 and 79-78 and "Collusion of Bambatha and Dinuzulu", 544-55. Cf. Binns, Dinuzulu, 197.

${ }^{114}$ Thompson, Bambatha at Mpanza, 84-86, and "Collusion of Bambatha and Dinuzulu", 546-50. 


\section{Rebellion at Mpanza}

Bhambatha returned to Mpanza at the end of March with four guns (one of them an old shot gun of his own, which he had apparently left with). He assembled the men of the Mpanza faction and brandished the Mauser rifle before them, saying Dinuzulu had given it to him to start the rebellion. Dinuzulu's two men attested to it. One left with the ersatz doctor, and the other remained, ostensibly to wait for the real one, but in fact he acted as Dinuzulu's agent and Bhambatha's keeper. ${ }^{115}$ He was Sukabhekuluma kaGezindaka, a young favourite of the king. He is better known in the literature by a white man's nickname for him, Chakijana, after a small cunning animal in Zulu folklore. ${ }^{116}$

Bhambatha raised an impi of about two companies, but it was obvious from the start that he was more interested in getting back the chieftaincy, not in fighting the poll tax. He struck on the night of 2-3 April to commandeer men from the other factions and to seize his brother Funizwe, who had been appointed chief, and his uncle Magwababa, who had been appointed regent. Funizwe escaped, but Magwababa did not. Bhambatha wanted to kill Magwababa straight away. It was all Sukabhekuluma could do to persuade him to give Magwababa a trial. His argument was that by killing Magwababa Bhambatha would split his tribe, just when it needed to be united. Magwababa was tried. Bhambatha said that he was guilty of conspiring with the authorities to have him deposed. He based this charge on the flimsiest of hearsay. Only one man supported Bhambatha, and then only because he was the chief. It was embarrassing. The men present, old and young, heard Bhambatha out, and then Magwababa, the preacher Moses, and Sukabhekuluma spoke. The assembly declared Magwababa innocent. Bhambatha went off and sulked. Magwababa was detained. Sukabhekuluma warned him that he would be killed if he tried to escape. ${ }^{117}$

Later the same morning the local magistrate and a squad of police went to Mpanza to find out what had happened to Magwababa. Near the Impanza hotel they were fired on and chased away by the impi, which then looted the hotel. The colonial police field force was

115 Thompson, Bambatha at Mpanza, 83-85, 98, 110; Cf. Stuart, Zulu Rebellion, 168; and Marks, Reluctant Rebellion, 205.

${ }^{116}$ Thompson, Bambatha at Mpanza, 87; Marks, Reluctant Rebellion, 276n; Cf. Stuart, Zulu Rebellion, 176.

117 Thompson, Bambatha at Mpanza, 82, 86-95; Cf. Stuart, Zulu Rebellion, 167-68; and Marks, Reluctant Rebellion, 205. 
dispatched to Greytown to deal with him. But first the commander, Colonel Mansel, was determined to rescue the magistrate and others, including two ladies and a child who had been at the hotel, who were in an improvised laager at Keate's Drift. Bhambatha had no intention of attacking the place, and the ladies were not particularly interested in being rescued, but the colonel did not know that, and in the afternoon of 4 April 150 police went down the road to Keate's Drift, rescued the ladies, and in the evening returned to the camp. It was an opportunity not to be missed. The rebels were doctored against the white man's bullets and led to the roadside, where Sukabhekuluma arranged an ambuscade. About nine o'clock the police column came along. The rebels attacked, shouting Usuthu! and throwing their spears. A melee ensued. The ambush in fact had miscarried. They had attacked only the police advance guard, which quickly rallied and fought its way back to the main column, which came forward firing, and the under-gunned and undisciplined rebels fled. The column closed up and continued to camp, harassed part of the way by snipers. Bhambatha and Sukabhekuluma claimed a victory. The police had run away from the battlefield. (Four policemen had been killed and four had been wounded). None of the rebels had been killed. (Four of them had been wounded, but not seriously). The medicine had worked. ${ }^{118}$

Bhambatha had defied the legally constituted government. He had reclaimed his chieftaincy by force, attacked the magistrate and then the police, and was now a rebel. The rebel force climbed to the top of Ndayi hill and waited for other rebel chiefs' forces to arrive. Bhambatha sent messages to come to Gayede of the amaKhabela, Silwana of the amaChunu, and Nyoniyezwe of the amaBomvu. None did. The amaBomvu under the acting chief Sibindi helped the government, which sent militia to reinforce the police. Bhambatha now had three large companies, but that was not enough to defeat the forces being arrayed against him. If he waited much longer he would be surrounded. After dark on 6 April the rebels left Mpanza and marched by night to the Khabela location, thence on 7 April to the Thukela and crossed into Zululand. On the march, half to two-thirds of the men, including Magwababa, deserted. $^{119}$

118 Thompson, Bambatha at Mpanza, 1-7, 96-109; Cf. Stuart, Zulu Rebellion, 168-77; and Marks, Reluctant Rebellion, 206.

119 Thompson, Bambatha at Mpanza, 95, 110-18; "Bambatha's Personal Rebellion", 62, and "Collusion of "Bambatha and Dinuzulu", 554-55. Cf. Stuart, Zulu Rebellion, 178-83; and Marks, Reluctant Rebellion, 20607. 


\section{Rebellion in Nkandla: The Usuthu Chiefs}

Across the river the rebels paused to eat and rest at a homestead in Mpumela's ward and then pushed on through the night and next morning to the Mhome Gorge, where they went into forest, concealed and protected by Sigananda, chief of the amaChube. Sukabhekuluma vouched for Bhambatha, said he had been sent by Dinuzulu to start the rebellion, and then went off to the Osuthu to report. ${ }^{120}$ Sigananda needed no convincing, but some of his headmen did, and messengers were sent to the Osuthu to get confirmation. ${ }^{121}$ Meanwhile the magistrate of the Nkandla Division and the Commissioner for Native Affairs in Zululand, who joined him on 9 April, showered orders on local chiefs to be on guard and to catch Bhambatha if he came their way. ${ }^{122}$ Sigananda professed to be looking for him but unable to find the rebels. Bhambatha's force remained under wraps in the forest until 13 April, when Sigananda brought out Bhambatha and announced that he, too, was a rebel to an assembly of sympathetic leaders and their men. ${ }^{123}$

\footnotetext{
${ }^{120}$ RSC III/3/1 Special Court: Zulu Rebellion, "Rex vs Cakijana”, (hereafter R. v Cakijana), evidence of Burala, 186-93, and of Cakijana 336-37. RSC III/3/2-7 Special Court: Zulu Rebellion, "Rex vs Dinuzulu" (hereafter R v Dinuzulu), evidence of Cakijana, 1529-35. Also, "Rex vs Sigananda", evidence of Linyana [sic] and Polomba, 126, MS transcript in the Colenso Collection, also in the PAR (hereafter R v Sigananda), a printed version of which appears in Bosman, Natal Rebellion, Appendix III, but there are discrepancies between it and the MS, and the latter has been preferred in this case. See also SNA I/6/26 GH 285/1906, "Nkandhla Court Martial no. 5" (hereafter GH 285/1906): evidence of Hlaza; and SNA I/6/27 GH 275/1906, "Nkandhla Court Martial no. 3" (hereafter GH 275/1906): evidence of Mgoqo. Hereafter in references to trials, "evidence of" will be dispensed with and only the name of the witness will be given. Cakijana, "Resume"; AGOI/7/55 "Interview (Durban Central Gaol) between J. S. Hedges and Ndabaningi kaSigananda and Lunyana, Sigananda's induna, 14 February 1907" (hereafter, Ndabaningi Interview); AGO I/7/80 "Statement of Burala, 24 April 1908". In references to declarations, depositions and statements, only the name of the person making the declaration, deposition or statement and the date will be given.

${ }^{121}$ R v Sigananda: Linyana, Maginga, Mgoqo; Ndabaningi Interview; James Stuart Archives (JSA) V, 152-54: Nsuze. Nsuze is an important source for Stuart, and much of his information appears in his Zulu Rebellion narrative (in this instance, 196-97). Unfortunately, Nsuze's statements were recorded in 1912, and Nsuze's recollection is sometimes much less than perfect.

${ }^{122}$ Colenbrander, "Account", 14-16. OD, 99, Commissioner for Native Affairs to Prime Minister (hereafter CNA and PM, respectively) 28 April 1906; CSO 3040, Secretary CNA to Defence, 7 April 1906, 25 and 30; PM 102 C226/1906 and SNA I/1/1203, Mgt Nkandhla to Minister of Native Affairs (hereafter MNA), 8 April 19069.03 a.m; SNA I/1/339 1203/1906, CNA to MNA, 8 April 1906; PM 102, C230/1906, "Synopsis of Wires received from 6 P.M. 7/4/06 to 6 P.M. 8/4/06", report of Mgt Nkandhla 8 April 1906, 9.30am. During the rebellion synopses of telegrams were compiled daily, and hereafter will be cited as "Synopsis" with the appropriate dates.

${ }^{123}$ Colenbrander, "Account", 15-17; $O D, 99-101$, CNA to PM, 28 April 1906; SNA I/6/27, R v Sigananda, Mgoqo; GH 282/1906, "Nkandhla Court Martial no. 2" (hereafter GH 282/1906): Mpikwa; JSA V, 156-60 and 178-79: Nsuze. It should be noted that Stuart, Zulu Rebellion, 198-202 misdates Sigananda's presentation of Bhambatha to the rebel assembly. His account of the doctoring which took place immediately afterward is unique, against which cf. ZA 23, R 25/ 1906 (Rex vs Tulwana): Mazombe.
} 
It is remarkable that when he escaped from danger at Mpanza, Bhambatha went straight to Sigananda. He was guided there, unhindered if not always welcomed en route. The evidence is fragmentary and unclear, but indicates that there was some communication between Dinuzulu and Sigananda and between Bhambatha and Sigananda and probably between all or some of them and other chiefs or influential headmen before this time. ${ }^{124}$ Those who adhered to the rebellion in the Nkandla had a background in the Usuthu party which had supported Cetshwayo and Dinuzulu in the civil wars and rebellion of the $1880 \mathrm{~s} .{ }^{125}$ They regarded the rebellion now as essentially Dinuzulu's, not Bhambatha's. ${ }^{126}$ They seem to have been primed for it; only the circumstances and timing were off. Bhambatha should have succeeded with this rebellion in Natal, not have failed. His sudden arrival in the Nkandla seems to have taken them, perhaps even Dinuzulu himself, by surprise. ${ }^{127}$

At this juncture Bhambatha ceased to be a leader of real consequence. His three companies, depleted by desertion and probably together numbering a little over 100 men, were consolidated into two. ${ }^{128}$ The Nkandla contributed ten to twelve companies to the rebel army. ${ }^{129}$ The camp of the army, about a thousand men, was located, strategically and symbolically, next to Cetshwayo's grave, near the confluence of the Nsuzi and Nkunzana streams. ${ }^{130}$ Bhambatha might enjoy some reputation in Natal, but not in Zululand. If he were

${ }^{124}$ With reference to Bhambatha in particular see Thompson, Bambatha at Mpanza, 86, 114-16, and "Collusion of Bambatha and Dinuzulu", 552-56; Perrett, "Dinuzulu and the Bambata Rebellion", 82-83; and R v Dinuzulu, 3033-57: Maliba (and also his statement on 26 October 1908, in the British Parliamentary Paper Command 4194, 81-82) and 4037-40, 4367-70, 4481, 4615, and Dinuzulu, 4690-92, 4852-58: Mankulumana. For circumstantial evidence see Ndabaningi Interview; ZA 34, CR18/1906, Mgt Babanango to Under Secretary for Native Affairs, 26 March 1906; and the Criminal Note Book (Martial Law), From no. 1/06 to 28/06, in the Archives of the Magistrate and Commissioner, Nkandla (1/NKA), 1/5/1/1/, no. 21: Mapoyisa.

125 See Stuart, Zulu Rebellion, 209-11; Perrett, "Dinuzulu and the Bambata Rebellion", 80-81; and Binns, Dinuzulu, 124. For context see John Laband, The Atlas of the Later Zulu Wars 1883-1888 (Pietermaritzburg: University of Natal Press, 2001) passim, and for "bits and pieces" see the British Parliamentary Papers, Command 4073: 30, 66, 100, 101-02, 118-19; 4191: 30-31, 40-41, 67, 85, 91-92, 94, 95; 4214: 46-47, 64, 65, $85 ; 4214: 5 ; 5522: 52-55$.

${ }^{126}$ Colenbrander, "Account", 17; OD, 102, CNA to PM, 28 April 1906; JSA V, 153: Nsuze; GH 282/1906: Mpikwa; AGO I/7/70 (and PM 104:C238/1906, which includes a précis of the statement, and SNA I/6/29): Mangati, 23 November 1907; GH 1462 (and SNA I/6/29): Mangati, 18 December 1907.

${ }^{127}$ Cakijana, Resume. R v Dinuzulu, 1532: Cakijana; JSA V, 152-54: Nsuze.

${ }^{128}$ R v Dinuzulu, 1531: Cakijana; SNA I/6/27 MJC 194/1906: Gwazizulu, Magondongwana, Masimba, Mbemi, Mkamangana, Nogalu, Sanqawe. See also Thompson, Bambatha at Mpanza, 116.

${ }^{129}$ The CNA estimated 12-14 companies numbering between 700 and 1000 men on 16 April (OD, 101, CNA to PM, 28 April 1906) and 10-13 companies on 1 May (GH 1465, Synopsis 1/ 2 May). The magistrate at Eshowe passed on a spy's report which gave 26 companies and a detailed breakdown by tribe. See PM 102, C226/1906, Mgt Eshowe to PM, 6 May 1906.

${ }^{130}$ Colenbrander, "Account," 17. R v Dinuzulu, 214-15: A. W. Leslie: 1543-45: Cakijana; 3457: Colenbrander; SNA I/6/27 GH 289/1906, "Nkandhla Court Martial no. 7" (hereafter GH 289/1906): Muti. GH 1462: Mangati, 18 December 1907. 
to maintain ascendancy among the rebels, he needed to display energy and skill. He did not. There is very little evidence of his having addressed either the councils of war or the men of the army. He may have proposed an attack the Nkandla magistracy - a bold stroke considering its distance from the forest and favourable field of fire - before the police field force secured it, and the rebels did move to the edge of the forest, apparently in readiness to do so, but the attack was called off by Sigananda, who was still waiting to hear from Dinuzulu. ${ }^{131}$ Aged and infirm the old chief might be, but he was quite lucid and enjoyed the respect of the Zulu peoples, which Bhambatha did not, and therefore he dictated the undertaking of operations. ${ }^{132}$

The Commissioner for Native Affairs practically staked his reputation on Dinuzulu's loyalty. ${ }^{133}$ Outwardly Dinuzulu was loyal and denounced "this dog" Bhambatha. The government wanted some token of proof. The commandant of militia suggested and Dinuzulu offered to lead - or since he was ill, have his principal adviser Mankulumana lead his armed men to the forest and undertake Bhambatha's capture. ${ }^{134}$ The Commissioner would not have it. Dinuzulu's force would be misrepresented by the rebels as the one he had promised. Bhambatha had told the rebels that Dinuzulu would send a force. Its presence in the Nkandla would create confusion, which would be to the advantage of the rebels. ${ }^{135} \mathrm{He}$ prevailed upon a grumpy Dinuzulu to send Mankulumana sans army to the forest to disavow

\footnotetext{
${ }^{131}$ Colenbrander, "Account", 16. Ndabaningi Interview. JSA V, 155-56: Nsuze. R v Sigananda: Linyana, Polomba, Simoyi; ZA 23, R25/1907: Ngcubana. SNA I/6/27 MJC 194/1906: Mbemi. Statement of Nongetsheni [n.d.] in the R v Sigananda file of the Colenso Collection.

${ }^{132}$ 1/NKA 3/2/1/2, Report of the Magistrate of Nkandhla Division in reply to Circular CNA no. 17/1906 [and] SNA Circular no. 11/1906, 23 July 1906; OD, 98 and 103, CNA to PM, 28 April 1906; Bosman, Natal Rebellion, 109-10; Stuart, Zulu Rebellion, 202 and 211; R v Cakijana, 125: Bova; 241, 249: Ndabazezwe.

${ }_{133} O D$, 28, Governor to Secretary of State, 23 February 1906; 76, Governor to Secretary of State, 20 April 1906; 99, CNA to PM, 28 April 1906; GH 1465 80, CNA's Report, 14 April 1906, quoted in Minister of Defence to Governor, 16 April 1906. Bosman, Natal Rebellion, 105-06. Stuart, Zulu Rebellion, 213.

${ }^{134} O D$, 77, [Dinuzulu to CNA, n.d.] and 102, CNA to PM, 28 April 1906. CSO 3040, CNA to PM 20 April 1906: 21.45; GH 1465 84, Commandant of Militia to Governor, 19 April 1906, and 93; Synopsis 18/19 April, CNA'S report 18 April 1906; R v Dinuzulu, 4489: Dinuzulu, and 4703: Mankulumana.

${ }_{135}$ OD, 76, Governor to Secretary of State, 20 April 1906 and 102, CNA to PM, 28 April 1906; CSO 3040, CNA to PM, 17 April 1906; GH 1465 87, Commandant of Militia to Governor, 17 April 1906 and 85, Synopsis 16/17 April, CNA's Reports 16 April 1906, and 93, Synopsis 18/19 April, CNA's Report 18 April 1906. Mankulumana states that he was opposed to sending a force in R v Dinuzulu, 4702. On the CNA's fears possibly having some foundation, see R v Dinuzulu, 1180, 1231, 1466, A. G. Daniels. The CNA was also opposed to Dinuzulu'a addressing loyal levies as it would give him undue authority (cf. Perrett's thesis). CSO 3040 and PM 102, C228/1906, CNA to PM, 5 June 1906 (and, in ZA 28) the same to the Officer Commanding, Zululand Field Force. See also SNA I/1/343, 1856/1906, "Notes on Interview between H E the Governor and the Envoys from Dinuzulu at Government House on 20h June 1906" (hereafter, Government House Interview).
} 
the rebels and to demand the surrender of Bhambatha. ${ }^{136}$ There is evidence that Mankulumana was delayed in order to allow Sigananda's messengers time to get back to the Nkandla before him. ${ }^{137}$

Mankulumana played his role well. On 25 April he told an assembly of rebels, led by Sigananda's son and heir Ndabaningi, the Ntuli rebel leader Mangathi, and also Sukabhekuluma (who had returned from the Osuthu), that Dinuzulu disavowed them and resented their using his name in connexion with Bhambatha. He also made it plain that he was sent to them at the behest of the government rather than Dinuzulu. ${ }^{138} \mathrm{He}$ had a message which he was to give only to Sigananda, but by design he was not allowed to talk to either Sigananda or Bhambatha. Sigananda's messengers had returned from the Osuthu with instructions that they should not meet him. ${ }^{139}$ Moreover Sukabhekuluma and his uncle Yena had returned to the Nkandla with affirmations of Dinuzulu's support. ${ }^{140}$ Yet there is evidence

${ }^{136}$ R v Dinuzulu, 1249-55: A. G. Daniels, 3533-57: G. W. Armstrong; 4053, 4055, 4488, 4492: Dinuzulu: 470305: Mankulumana; and AGO I/7/78, "Notes of further interview between HE the Governor and Anthony Gideon Daniels at Government House 24 December 1906"; and I/7/75, "Statement by Anthony Gideon Daniels before T. R. Bennett, the Pietermaritzburg Central Gaol, 18 March 1908" (cf. I/7/55, where a typescript is dated 23 March 1908).

${ }^{137} \mathrm{R}$ v Dinuzulu, 4054, 4483, 4485: Dinuzulu; 4706, 4854: Mankulumana; Government House Interview; JSA V, 156: Nsuze; AGO I/7/78, "Governor's interview with Daniels", 24 December 1906; R v Sigananda: Polomba. On a possible third messenger, sent specially by Dinuzulu to Sigananda, see R v Sigananada: Maginga.

${ }^{138}$ R v Dinuzulu, 2790-2791, 2829: Mangati; 4708-20, 4825-54: Mankulumana; 5191-5207: Nopungwa; 522831: Godi. R v Cakijana, 344-46: Cakijana; R v Sigananda,: Linyana, Maginga, Polomba, Simoyi; Government House Interview; Ndabaningi Interview; AGO I/7/68 (and PM 59 463/1906): Mankulumana, 27 April 1906. Mankulumana went to the forest on 23 April and returned from it on 27 April 1906. The evidence on his mission may be divided into four categories, in chronological order: and a "government" version ("early" Mankulumana, with an official gloss); a "rebel" version (Ndabaningi and Sigananda's headmen), a "renegade" version (Mangathi and Sukabhekuluma); and a "royal" version (Dinuzulu and Mankulumana and the Osuthu dependants).

${ }^{139}$ The public message was similar to that Mankulumana gave, and the secret message was that Dinuzulu was sympathetic, but Mankulumana should not see Sigananda or Bhambatha. JSA V, 156: Nsuze; and Stuart, Zulu Rebellion, 203; R v Sigananda: Maginga, Mgoqo, Ndabaningi; Cakijana, "Resume"; R v Cakijana, 1816: Cakijana. For the fall-out from this see R v Dinuzulu, 2637-38: Langalibomvu; 2784, 2790-91, 2832: Mangati; 4713: Mankulumana; AGO I/7/68, Mankulumana, 27 April 1906; Government House Interview; GH 1462: Mangati, 18 December 1907; and GH 289/1906: Lunyana; and R v Sigananda: Polomba. Mankulumana's twofacedness in this affair seems to have been appreciated readily by the rebel leaders, but not, of course, by their followers.

${ }^{140}$ Sukabhekuluma had returned to the Nkandla from the Osuthu on or about 18 April, and rejoined Bhambatha. He reported that Dinuzulu was coming, but not yet. His usefulness to Dinuzulu was at an end, because he had been identified by name by the authorities. AGO I/7/70 (and 79): Ngqengqengqe, 27 April 1908; and I/7/66: R v Cakijana: Cakijana; R v Dinuzulu, 1921: Cakijana. Mangathi observed that Mankulumana was not surprised to see Sukabhekuluma at the assembly on 25 April — see GH 1462, 18 December 1907-although Lunyana (R v Sigananda) states that Sukabhekuluma was not there. Sukabhekuluma's uncle Yena, an elusive and evasive figure, returned from the Osuthu on or about 16 April and also reported, but his message, although evidently encouraging, is not given. Cakijana, "Resume"; SNA I/6/29 CR 137/1907, Mangati, 26 November 1907. 
that suggests that Mankulumana had secret talks with Sigananda and with Bhambatha's officer Mkamangana and preacher Moses. ${ }^{141}$ On his return from the forest he told the Commissioner that he had made no headway with the rebels. ${ }^{142}$

Not surprisingly, instead of discouraging the rebels, as the Commissioner wistfully reported, Mankulumana's mission seemed to encourage them. ${ }^{143}$ They became aggressive in raiding neighbouring chiefdoms which remained loyal to the government. ${ }^{144}$ The chiefs Ndube, and later on, Mpumela and Mbuzo, who had hesitated while most of their tribesmen joined the rebels, sought the protection of the government. ${ }^{145}$

\section{Bhobe: The Discredit of Bhambatha}

Meanwhile the government sent police and militia to the Nkandla. These forces secured the magistracy and also took position at Fort Yolland and Ntingwe. Thus they restricted the rebels' area of operations and seized the strategic initiative. ${ }^{146}$ On 5 May Colonel Mansel made a reconnaissance in force towards the rebel base, and the force there sallied to meet it. Bhambatha argued for an attack in the bush and not in the open, but evidently Sigananda (and Sukabhekuluma) did not agree with him. The enemy was coming down the bare spine

\footnotetext{
${ }^{141}$ In the case of Sigananda it seems less than likely (see R v Dinuzulu, 2639-2641: Langalibomvu, and 50955099: Gcoyane), but in the case of Bhambatha's men, rather more likely. See R v Sigananda: Maginga, Mgoqo, but cf. Polomba (who denies flatly) and Linyana and Simoyi (who hedge); AGO I/7/54 and 70: Ngoqo, 6 April 1908; Cakijana, "Resume"; and R v Cakijana, 344-345: Cakijana.

${ }_{142}$ Mankulumana's statement, 27 April 1906, taken down by Stuart, is in AGO I/7/68 and PM 59 463/1906. See also GH 1465 112: Synopsis 26/27 April, CNA’s Report, 27 April 1906; Colenbrander, “Account”, 17-18; R v Dinuzulu, 3481: Colenbrander.

${ }^{143}$ The CNA reported that Mankulumana's mission had a discouraging effect $(O D, 102,28$ April 1906, and 115, 8 May 1906), but the magistrate thought quite otherwise ( $\mathrm{R} v$ Dinuzulu, 3484: Colenbrander), and events immediately following bear him out. See also ZA 34 CR 24/1906, Mgt Emtonjaneni to CNA, 15 May 1906; and PM 102 C226/1906 (also quoted in GH 1465, 114, Synopsis 27/28 April), Mgt Eshowe to PM, 27 April 1906, 16.55; and R v Sigananda: Mgoqo.

${ }^{144}$ GH 1465 117: Synopsis 29/30 April, Reports of the Officer Commanding, Umvoti Field Force, 29 April: 17.00, Intelligence, Krantzkop, 30 April: 15.30, CNA, 29 April: 21.20, Mgt Eshowe 30 April 1906: 10.30, and Mgt Krantzkop [n.d.]; 142; and Synopsis 13/14 April 1906, OC Troops, Eshowe, to Defence, 11 May 1906: 21.40; and 146: as well as Synopsis 13/14 May 1906, OC UFF, 14 May 1906. Also CSO 2599 C147/1906, Umvoti Field Force Diary, 28-30 April 1906, and 3040: Mgt Eshowe to PM, 30 April: 13.08, and 14 May 1906: 17.15; and Natal Witness, "Rebels Looting", 5 May 1906.

${ }^{145}$ Ndube fled on the night of 22-23 April. GH 275/1906: Ndube. GH 1465, 103: Synopsis 22/23 April, reports of OC UFF 12.50 and CNA [n.d.]; JSA, I, 164-65: Hayiyana. Mbuzo fled on 13 May; GH 1465, 146: Synopsis 13/14 May, OC UFF's Report 14 May 1906; and 151: Synopsis 17/18 April: Magistrate Krantzkop's Report 18 May 1906. Mpumela fled on 14 May. See GH 1465, 148: Synopsis 15/16 May, Reports of OC UFF 13 May and Intelligence Krantzkop 15 May 1906; and CSO 3040, Mgt Krantzkop to PM, 16 May 1906: 17.10.

${ }^{146}$ See Stuart, Zulu Rebellion, 216-219, and Thompson, Historical Atlas, 18-21.
} 
of Bhobe ridge towards the grave. He was in the open and had to be stopped there: the rebels could not choose their ground. It was a hot day, and the enemy column was strung out after a hard march. It might be defeated in detail. Sigananda's and Ndube's men (probably commanded by Ndabaningi and Macwaneka, respectively), were concealed in the rugged features of the ground. They charged only when they were discovered by the enemy's van. They showed great dash, but the enemy quickly formed and repelled them with rifle fire. After about twenty minutes trying to get hand-to-hand with him, they broke and fled down the slopes of the ridge. Meanwhile Bhambatha led his men through bush along the Nkunzana to flank or turn the enemy column on the left. The enemy at the rear perceived this movement and opened fire at long range. After firing a few shots in reply, Bhambatha's companies retreated. The enemy column closed up, but, instead of proceeding towards the grave, turned aside and marched back to Fort Yolland. ${ }^{147}$

The battle of Bhobe ridge was a turning point in the rebellion. ${ }^{148}$ The rebels claimed that the enemy had run away and left them in possession of the battlefield, just as at Mpanza. But this time they had suffered heavy losses - between sixty and seventy killed and many more wounded. ${ }^{149}$ Bhambatha's medicine did not work. His doctors had failed. Bhambatha argued that Sigananda's men had spoilt the medicine by sleeping and having sex with their wives and sweethearts after they had been doctored. He also blamed them for their bad tactics. ${ }^{150}$ His men had suffered no casualties whatever, because they did not engage at all.

${ }^{147}$ For attempts to describe the action from both sides see Stuart, Zulu Rebellion, 230-35, and Thompson, Historical Atlas, 22-23. For the reports of the Natal Police Commander Colonel Mansel see CSO 2599, C147/1906, Colonel McKenzie's report which incorporates Mansel's, and the separate Diary of the Natal Police Reserve Force; and 3040 (and GH 1465 132), Mansel to Defence, 6 May 1906. The colonial side is dealt with in Bosman, Natal Rebellion, 31-33; H. P. Holt, The Mounted Police of Natal (London, Murray, 1913), 203-08; A. H. G. Blamey, My Verulam Troop (Umzumbi: private, 1954), 15-24; and Ethel Campbell, The Life of Sam Campbell (Durban: private, 1933), 263-64. Also see Natal Mercury, "The Nkomo fight", 9 May, 1906 and "Nkandhla News", 12 May 1906. The rebel side may be reconstructed from extensive but fragmentary evidence in Cakijana, "Resume"; R v Cakijana, 125-26: Bova; 140: Baletshe; as well as the MS transcripts in AGO I/7/58 and 66, for Bova and Cakijana, respectively; R v Dinuzulu, 1545, 1827-29: Cakijana, and 2792: Mangati; R v Sigananda: Ndabaningi and Polomba; GH 275/1906: Dunga; GH 282/1906: Polomba.; GH 289/1906: Muti; GH 1462 and SNA I/6/29: Mangati, 18 December 1907; AGO I/7/80: Baletshe, 24 March 1908, and Msolwa, 8 April 1908; SNA I/6/27, MJC 194/1906: Mpetempete, Nogalaju, Sikukula; and the Archives of the Magistrate and Commissioner, Weenen (hereafter 1/WEN) 1/4/21, "Martial Law. Note Book", no. 20/1906: Mcitsho.

${ }^{148}$ Colenbrander, "Account", 19-20; Stuart, Zulu Rebellion, 235; Natal Mercury, "Natives Surrendering", 7 May 1906; and R v Sigananda: Mgoqo.

${ }^{149}$ This is the police estimate. See CSO 2599 C147/1906, Natal Police Diary. Others range between 50 and 100 killed. A very conservative estimate based on eight rebel sources gives at least 47 killed.

${ }_{150}$ JSA V, 178-79: Nsuze; GH 1462 and SNA I/6/29: Mangati, 18 December 1907; R v Dinuzulu, 2792: Mangati. Sigananda sent messengers to Dinuzulu, who blamed the defeat on the sally in the open. See R v Sigananda: Mgoqo, Ndabaningi, and Polomba. 
Sigananda's people were angry. It appeared that Bhambatha had deceived them and fought shy of the battle. The women threatened him. Fearing for his life, Bhambatha hastened to Macala hill, where Mangathi's force was based. ${ }^{151}$ Sukabhekuluma accompanied him, of course. Bhambatha became ill - Sukabhekuluma said he had a stitch in his side - and for nearly a fortnight he remained secluded in the hut which Mangathi allotted him. ${ }^{152}$

Manifestly Bhambatha was a flawed leader. First, he had turned the rebellion at Mpanza into a personal vendetta, and had to be checked by Sukabekhuluma. Second, he had failed to enlist the majority of his tribe in the rebellion, and failed to get the support expected of other chiefs in Natal. Third, at the battle of Bhobe, his medicine did not work and he himself did not fight, so that he looked like a liar and a coward, and then he had left his own men in the Nkandla ${ }^{153}$ for the more hospitable camp of Mangathi. He was little more than a tarnished symbol. He no longer commanded anyone. Friend and foe might still conjure with his name, but he no longer influenced operations. There is no report of him in the subsequent fighting at Dlolwana, Msukana and Silokomane.

The government build-up continued. The government manifestly had the men, the guns, the force and the will to win. The rebels looked in vain for help from Dinuzulu. ${ }^{154}$ They began to lose more adherents than they attracted. ${ }^{155}$ Chiefs like Gayede, Hlangabeza and Thulwana, who had been "chewing with both jaws", stopped and came down squarely on the winning side. ${ }^{156}$ Colonel Duncan McKenzie arrived at the Nkandla magistracy in command

151 JSA II, 203: Mangati, and V, 178-79: Nsuze; and Stuart, Zulu Rebellion, 236.

${ }^{152}$ JSA V, 160-61: Nsuze; GH 1462 and SNA I/6/29: Mangati, 18 December 1907; R v Cakijana, 346-47: Cakijana; R v Dinuzulu, 1547, 1827-28: Cakijana; R v Sigananda: Mgoqo, Ndabaningi.

${ }^{153}$ Colenbrander, “Account”, 20; JSA V, 161: Nsuze; R v Cakijana, 126: Bova; R v Dinuzulu, 1547: Cakijana.

${ }^{154}$ See P. S. Thompson, "Crossroads of War: The People of Nkandla in the Zulu Rebellion of 1906", Scientia Militaria 35, no. 2, 2007, 105-06. Dinuzulu and others at the Osuthu were distracted and embarrassed at this time by a scare that a government force was descending on the Osuthu and by the murder of the Mahlabatini magistrate H. M. Stainbank on 3 May. See Colenbrander, "Account", 19; Stuart, Zulu Rebellion, 219-21; Marks, Reluctant Rebellion, 254 and 298-99; R v Dinuzulu, 1291: A. G. Daniels; GH 1286, 98-113, CNA to PM, 11 September 1906; SNA I/4/22, C22/1909, “General Report on the Stainbank Murder”; AGO I/7/54, Mgt Mahlabatini to Attorney-General, "Précis of evidence and copies of depositions"; and ZA 28, R v Umpeta and others", 22 August 1908.

${ }^{155}$ Colenbrander, “Account”, 19-20; Natal Mercury, "Natives Surrendering”, 7 May 1906; GH 1462 (and SNA I/6/29): Mlonyeni, 6 December 1907 and 1465, 134: Synopsis 7/8 May: Intelligence Krantzkop's Report, 8 May 1906, and 138: Synopsis 9/10 May: Reports of Intelligence Krantzkop and Chief Commissioner of Police, Fort Yolland [n.d.]; SNA I/6/27: MJC 194/1906: Sofuguza; Archives of the Magistrate Greytown (1/GTN) 1/3/2/1, "Cases tried under Martial Law at Magistrate's office, Greytown 1906", no. 12: Madolo, Umtshekula, Umgwempisi, Umziki, Umpendu, Ujoni, Mazikwempi.

${ }^{156}$ SNA I/1/342, 1684/1906, Report of the Chief Intelligence Officer, Umvoti Field Force, Krantzkop, 27 May 1906, on Amakabela tribe; GH 285/1906: Nongqai; 1/NKA 1/5/1/1, no. 11: Tulwana (Mtshule) and 2, no. 39: Nqakamatshe; ZA 23, R 25/1907, Makula, Maxibane, Mcetshwa, Mfokazi, Sambana; and Natal Mercury, "Krantzkop Rumours", 10 May 1906: 
of the Zululand Field Force. Across the Thukela was the Umvoti Field Force under Colonel George Leuchars. On 17 May these forces converged on the rebel base at Cetshwayo's grave. The rebels were surprised and fled, and their camp was destroyed. ${ }^{157}$ Only Mangathi showed fight, but he failed to cut off the rearguard of one column at Msukana and then to draw the van of another at Silokomane, ${ }^{158}$ where incidentally Sukabhekuluma was wounded and put out of action for a fortnight. ${ }^{159}$

Sigananda now proposed to surrender, and an armistice was granted so that he could arrange the matter with his people. After five days the armistice expired and there was no surrender. ${ }^{160}$ On 21 May a column destroyed Mangathi's camp at Macala Hill. Mangathi prudently withdrew ahead of it to a new camp in the Ekombe forest, on the Qudeni range. ${ }^{161}$

\section{Revival of Rebel Fortunes}

By this time Bhambatha had recovered, and he and Mangathi went to the Osuthu to find out what was keeping Dinuzulu. ${ }^{162}$ According to Mangathi, he himself did most of the talking. Bhambatha complained about Sigananda's losing at Bhobe and asked Dinuzulu to appoint some able leaders. ${ }^{163}$ He also visited his wife and children. ${ }^{164}$ Bhambatha and Mangathi were there three days, and Dinuzulu told them to go and join Mehlokazulu, a prominent chief in

157 Colenbrander, "Account", 21-22; Bosman, Natal Rebellion, 37-43; Stuart, Zulu Rebellion, 237-43; Thompson, Historical Atlas, 24-25.

${ }^{158}$ GH 1462 and SNA I/6/29: Mangati, 18 December 1907; Stuart, Zulu Rebellion, 241-42; W. J. Powell, The Zulu Rebellion of 1906: A Souvenir of the Transvaal Mounted Rifles (Johannesburg, Transvaal Leader, 1906), 29, 31-32.

${ }^{159}$ Cakijana, "Resume"; R v Cakijana, 147: Msolwa, and 347-348: Cakijana; PM 104, C238/1907, Mangati, 23 November 1907; AGO I/7/80: Mangati, 27 March 1908; SNA I/6/27: MJC 194/1906, Mpetempete.

${ }^{160}$ Colenbrander, "Account”, 22-23; Bosman, Natal Rebellion, 47-52 passim; Stuart, Zulu Rebellion, 245-49.

${ }^{161}$ Bosman, Natal Rebellion, 49-50; Stuart, Zulu Rebellion, 246; GH 1466, 4: Synopsis 24/25 May 1906, Report of R. H. Addison [n.d.]; Archives of the Magistrate and Commissioner Babanango (1/BGO) 1/4/1/1, "Native Rebellion. Note Book 1906" 1/8/1: Kawulana.

${ }^{162}$ Stuart, Zulu Rebellion, 313-14; Marks, Reluctant Rebellion, 216-17. Mangathi is the chief informant with regard to this visit, but there are significant differences between his depositions and trial evidence. See PM 104, C238/1906, 23 November 1907; GH 1462 and SNA I/6/29, 18 December 1907; AGO I/7/54, 8 November 1908; R v Cakijana, 160-63; R v Dinuzulu. 2793-2804, 2810-12, 2834-36, 2839-47, 2869-70.

${ }^{163}$ AGO I/7/54: Mangati, 8 November 1908; R v Dinuzulu, 2975-78 and 2800-02: Mangati.

${ }^{164}$ SNA I/6/29, Depositions of Siyekiwe, 5 and 12 July and 23 December 1907; of Kolekile, 13 September and 24 December 1907, and Ndabayake, 19 July 1907; R v Dinuzulu, 254-59 and 313: Siyekiwe; 361-65, Kolekile; 451-53: Ndabayake. See also PM 104, C238/1907, Mangati 23 November 1907; GH 1462 and SNA I/6/29: Mangati, 18 December 1907; R v Cakijana, 165: Mangati. 
the Nqutu Division who had rebelled. ${ }^{165}$ Mangathi says that Bhambatha did not want to return to the fighting and he had to force him to go back. ${ }^{166}$ On trial Dinuzulu admitted to one brief interview with Mangathi, whom he scolded for bothering him and then sent packing; but he did not have him arrested. He denied absolutely that Bhambatha was there at all. ${ }^{167}$

By the beginning of June the strategic situation had altered radically, and Dinuzulu might well have looked forward to a change of fortunes. Mehlokazulu's army was composed of nine to fourteen companies from various chiefdoms of the Nqutu and Umsinga divisions which had gone over to rebellion very belatedly, thanks to confused and ineffectual leadership, typified by Mehlokazulu himself. ${ }^{168}$ Different portions of his force had had disastrous encounters with government forces at Elandskraal on 12 May and Mpukunyoni on 28 May, and they had no illusions about the white man and his bullets. Mehlokazulu moved towards the Nkandla to avoid a government field force operating near Isandlwana. His impi and those of Mangathi and Sigananda (including Bhambatha's lot) came together in the Ekombe. ${ }^{169}$ The combined forces numbered perhaps thirty-five to forty companies, with a strength of between twelve and fifteen hundred men. ${ }^{170}$ It moved down to the Thukela, as if

${ }^{165}$ PM 104, C238/1907, Mangati, 23 November 1907; GH 1462 and SNA I/6/29: Mangati, 18 December 1907; AGO I/7/54: Mangati, 8 November 1908; SNA I/6/29: Siyekiwe, 12 July and 23 December 1907; R v Dinuzulu, 2798-2800 and 2834-36: Mangati; R v Sigananda: Polomba; Marks, Reluctant Rebellion, 285-86.

${ }^{166} \mathrm{R}$ v Dinuzulu, 2820 and 2828-29: Mangati.

${ }^{167} \mathrm{R}$ v Dinuzulu, 4072-74, 4227, 4230-4232, 4239-43, 4442-45, 4451-53, 4455-62: Dinuzulu; 4728-31, 484042, 4883-89: Mankulumana. See also the supporting evidence of Njinjini, in ibid., 5259, 5243-44, 5271-76; R v Sigananda; and AGO I/7/70, 27 November 1907. The Court seems to have been inclined to believe Dinuzulu, and reluctantly accepted the disparate evidence of Mangathi, Siyekiwe and others - see Trial of Dinuzulu, viiiix, xiv-xv, 25, 67, 79-83. Yet apart from their evidence, there is circumstantial and peripheral evidence supporting Bhambatha's being at the Osuthu. See and cf. the following: GH 1465 154: Synopsis 20/21 May, Intelligence Krantzkop's report [n.d.], and 1466 2: Synopsis 23/24 May, reports of OC UFF and Intelligence Krantzkop [n.d.], and 1466 12: Synopsis 26/27 May, OC UFF report 26 May 1906: 11.00; Natal Mercury, "Bambata's Whereabouts", 28 May 1906, and Times of Natal, "Gone North", 28 May 1906; OD, 145, CNA to PM, 29 May 1906; SNA I/1/344, 2051/1906: Muziwaka, 27 June 1906; R v Dinuzulu, 737-38: Mahayihayi; 1194-99: Daniels; 6113-15: Okalingenisa; AGO I/7/76: Sicoto, 24 May 1908.

${ }^{168}$ Stuart, Zulu Rebellion, 266-67 and 277-78; Marks, Reluctant Rebellion, 222; Thompson, Historical Atlas, 28-29 and 34-35. See estimates of strength in GH 1466, 35: Synopsis 30/31 May, OC UFF Report 31 May 1906, and 38: Synopsis 31 May/1 June, CNA's Report 31 May 1906, citing Mpikwa, and OC ZFF report 31 May 1906; also Powell, Zulu Rebellion, 42.

${ }^{169}$ Stuart, Zulu Rebellion, 266-79 and 319-28; Bosman, Natal Rebellion, 56-59; Thompson, Historical Atlas, 2034 passim.

${ }^{170}$ The strength of the force is a subject of much conjecture, owing to many different reports at the time. The figures here are from GH 1466, 32-33: Synopsis 30/31 May, OC UFF Report 31 May 1906, and 38: Synopsis 31 May/1 June, CNA’s report 31 May 1906; and OD, 161, CNA to PM, 1 June 1906. 
to invade Natal, then moved to the Macala, and finally shifted to the East. ${ }^{171}$ The Emtonjaneni and Eshowe divisions were agog with rumours of an imminent general rising. ${ }^{172}$

Mangathi announced to the impi that Dinuzulu had appointed Macala, a leader of Ndube's rebels, as supreme commander, and Mganu, one of Sigananda's headmen to command the Mavalana ibutho, an age set of young men recently embodied by Dinuzulu. Mangathi also said that Bhambatha and he had been made princes. ${ }^{173}$ Bhambatha rode with the leaders of the army, but he seems to have had no input in their councils. The defects of rebel leadership may have been rectified in respect of Sigananda's and Mangathi's units, but not for Mehlokazulu's and such was Mehlokazulu's reputation that he dominated the councils. $^{174}$

It is not clear what the rebel leaders intended. Sigananda's people had suffered greatly from a series of "drives" by McKenzie's troops, which had destroyed homesteads and captured livestock. ${ }^{175}$ Sigananda called on the army for help. ${ }^{176}$ It has been suggested that the army would go to the Mhome gorge and lie in wait to ambush the government forces in the forests there, although this would be playing old tactics and it is doubtful that food would be sufficient to sustain it. ${ }^{177}$ Other evidence suggests that the army was indeed heading eastward, in which case it would most likely support a rising there. ${ }^{178}$

\section{Defeat, Death, and Apotheosis}

\footnotetext{
${ }^{171}$ Thompson, Historical Atlas, 34-37, and “Crossroads of War", 117-18; Stuart, Zulu Rebellion, 314-15, suffers because of Nsuze's confusion about the timing of the demonstration at the Thukela misdating (see JSA V, 161). ${ }^{172}$ ZA 28, CNA to OC ZFF, 2 June 1906, and to PM, 12 June 1906, and 34, CR 29/1906, Mgt Empangeni to CNA, 13 June 1906; CSO 3040, Mgt Eshowe to PM, 25 June 1906: 17.40; Cakijana, "Resume"; Natal Mercury, "The Illusive Bambata", 6 June, and "Native Rebellion", 9 June 1906; Natal Witness, "Rebel Opinions: Strange Thesis", 9 June 1906; and Times of Natal, "Natal Parliament. Legislative Assembly. Zululand Rumours", 7 June 1906.

${ }^{173}$ Stuart, Zulu Rebellion, 314, based upon Nsuze in JSA V, 162; Cakijana, "Resume"; R v Cakijana, 349: Cakijana.

${ }^{174}$ PM 104 C238/1907, Mangati, 23 November 1907; R v Dinuzulu, 1776: Cakijana, and 2691: Mazwi; SNA I/6/27 MJC 194/1906, Nkonywana; R v Sigananda: Ndabaningi.

${ }^{175}$ Bosman, Natal Rebellion, 60-77; Stuart, Zulu Rebellion, 251-55; Thompson, Historical Atlas, 31-33, and "Crossroads of War", 110-16.

${ }^{176}$ Stuart, Zulu Rebellion, 314-15, based on Nsuze in JSA V, 161; Thompson, "Crossroads of War”, 118.

${ }^{177}$ Colenbrander, "Account”, 29; Stuart, Zulu Rebellion, 297-98; Thompson, "Crossroads of War", 118-19.

${ }^{178}$ Thompson, "Crossroads of War", 118.
} 
The army arrived at the mouth of the Mhome gorge after a long and tiring march on the evening of 9 June, and bivouacked without throwing out sentries. ${ }^{179}$ Sukabhekuluma, recovered from his wound, smelt a rat and joined a lone company which remained at the Macala. ${ }^{180}$ In the course of the night there were intimations of the enemy's approach, and Mangathi and then Ndabaningi took their followers into the gorge for safety, but Mehlokazulu dismissed the reports, and Bhambatha stuck with him. Too late did they realize their error. At dawn the enemy opened a murderous fire and cut off escape up the gorge. Nothing is said of Mehlozkazulu in all this, but there is a report that Bhambatha panicked, and that Mganu took charge and tried to retrieve the situation with a futile charge which broke up under the heavy fire. Those who managed to flee from the mouth of the gorge took refuge in a small forest just above it and were hunted down in the afternoon. About 500 men died in the massacre, including Bhambatha and Mehlokazulu. ${ }^{181}$

The rebellion in the Nkandla collapsed as a result. Sigananda and Ndabaningi surrendered a few days later, and most of the surviving rebels followed their example. Mangathi and Sukabhekuluma became fugitives. ${ }^{182}$ Militia intelligence identified a body in the gorge as Bhambatha's. The head was cut off and brought to the camp, where it was shown to those who would recognize it. The intention was to pre-empt stories that Bhambatha had run away to fight another day. Ndabaningi and others saw the head and said it was Bhambatha's, and it was good enough Bhambatha's for the time being. After two days it was returned to the body in the gorge and buried with it. ${ }^{183}$

In the unsettled times after the rebellion reports did circulate that Bhambatha had escaped and was preparing to renew the fight, but no witness ever appeared who had actually seen him. Mangathi and Sukabekuluma believed he was dead. Dinuzulu told Siyekiwe that her husband was dead, but, of course, he was in no position to make a definitive pronouncement. If anyone wanted Bhambatha out of the way, it would be Dinuzulu. Dead

\footnotetext{
${ }^{179}$ Stuart, Zulu Rebellion, 315-16.

${ }^{180}$ Cakijana, "Resume"; R v Cakijana, 349-350: Cakijana; R v Dinuzulu, 1777-78: Cakijana; AGO I/7/54: Tshwapana, 20 December 1908.

${ }^{181}$ Bosman, Natal Rebellion, 78-94; Stuart, Zulu Rebellion, 299-313 and 315-17; Thompson, Historical Atlas, 36 and 38-39.

${ }_{182}$ Bosman, Natal Rebellion, 105-10; Stuart, Zulu Rebellion, 333-35; Thompson, Historical Atlas, 36-37; PM 104, C238/1907, Mangati, 23 November 1907; Cakijana, "Resume".

${ }^{183}$ Bosman, Natal Rebellion, 107-08; Stuart, Zulu Rebellion, 336-38; P. S. Thompson, "Bambatha after Mome: Dead or Alive?" Historia 50, no. 1, May 2005, 23-31. See Guy, Remembering the Rebellion, 129-131, for photographs said to be Bhambatha's head.
} 
men tell no tales. After Dinuzulu was arrested for complicity in the rebellion, at the end of 1907, the stories about Bhambatha tailed off. ${ }^{184}$

Thus the career of the rebel leader Bhambatha kaMancinza. Heritage and History are distinct entities, and there are two Bhambathas. One is the icon of the centenary celebrations. The other is the mortal in the historical evidence. It has been the purpose of this article to describe Bhambatha's career as a rebel leader. Its thesis is that he was a weak leader, who had to be kept to his duty by others, notably Sukabhekuluma and Mangathi. He mishandled the rebellion at Mpanza, and lost control of it in Nkandla. He had rivals for command there, of course, but he had a high reputation, at least initially. He seems to have lost that, too, at Bhobe.

Bhambatha's story is a tragic one, of an unhappy, unstable man driven to recklessness and to danger. The centenary celebrations made him out to be a hero and a martyr. If anything he was a hapless victim of circumstances. He displayed none of the courage associated with heroes. He appears to have been the tool of someone at the Osuthu - it is very tempting to say that it was Dinuzulu, but we cannot be sure it was he - and during the rebellion he was very much in the hands of Sukabhekuluma, and, after Sukabhekuluma was wounded, the dependant of Mangathi. It may be called Bhambatha's rebellion, but to the rebels themselves it was really Dinuzulu's rebellion.

\footnotetext{
${ }^{184}$ Thompson, "Bambatha after Mome", 32-34.
} 